\title{
A cytomorphometric analysis of the oral mucosa in patients with type 2 diabetes mellitus
}

\author{
Lamichhane RS ${ }^{1}$, Boaz K ${ }^{2}$, Natrajan $\mathrm{S}^{2}$, Shrestha $\mathrm{M}^{3}$ \\ ${ }^{I}$ Department of Oral and Maxillofacial Pathology, Kist Medical College, Lalitpur, Nepal. \\ ${ }^{2}$ Department of Oral and Maxillofacial Pathology and Oral Microbiology, Manipal college of Dental Surgery, Mangalore,India. \\ ${ }^{3}$ Department of Oral and Maxillofacial Pathology, Chitwan Medical College Teaching Hospital, Bharatpur, Nepal
}

\section{Keywords:}

Cytomorphometry; Diabetes mellitus; Oral exfoliative cytology; Morphology.

\section{INTRODUCTION}

Diabetes mellitus designates a group of metabolic diseases characterized by hyperglycemia due to insufficient

\footnotetext{
Correspondence:

Dr. Ram Sudhan Lamichhane, BDS, MDS

Department of Oral and Maxillofacial Pathology

Kist Medical College, Imadol, Lalitpur, Nepal

Email:drramsudhan@gmail.com
}

\begin{abstract}
Background: Although many of the pathological conditions of oral mucosa are clinically distinguishable, most lesions require a definitive diagnosis. This article tried the use of exfoliative cytology as an alternative tool in the screening, diagnosis and follow-up of diabetes mellitus.

Materials and Methods: After rinsing the mouth with normal saline, slides were prepared from buccal mucosa and dorsum of tongue and fixed in $95 \%$ ethyl alcohol. The slides were stained with Papanicolaou stain and Acridine orange. Fifty clearly defined cells in each slide were visualized under light microscope for cytomorphometric analysis of cells using Image $\mathbf{J}$ software and under fluorescence microscope for assessment of nuclear alterations like micronuclei, nuclear budding, binucleation, multinucleation and karyorrhexis.

Results: Statistically significant increase in Nuclear area BM $(p=0.000057)$, Nuclear Area Tongue $(p=$ $0.0000113)$, total Nuclear Area $(p=000079)$, Cellular Area BM $(p=0.0475)$, Cellular Area Tongue $(p=$ 0.0105), Total Cellular Area ( $\mathrm{p}=0.00496)$, Cytoplasmic Area Tongue $(\mathrm{p}=0.00358)$, Total Cytoplasmic Area $(p=0.00268)$ were obtained from epithelial cells in the diabetic group when compared with the control group. Also the epithelial cells from the diabetic group showed features such as nuclear budding, micronuclei, binucleation, karyorrhexis and perinuclear halo.

Conclusion: The objective demonstration of cytomorphometric and nuclear alterations by the oral exfoliated cells indicate the presence of cytological changes in the oral mucosa of diabetic patients despite the apparently normal clinical appearance. Hence, cytomorphometric analysis would aid the health professional as an additional non-invasive tool for the screening and monitoring of Diabetes Mellitus.
\end{abstract}

insulin secretion and/or reduced insulin sensitivity, and associated with abnormal metabolism of glucose, lipid and protein. The chronic hyperglycaemia leads to an increased risk of development of microangiopathy, accelerated atherosclerosis, neuropathy and impaired wound healing. ${ }^{1-3}$ The main complications associated with diabetes mellitus are retinopathy, neuropathy, nephropathy and macro/microangiopathy. Further, DM damages tissue 
repair processes and causes dysfunction of oral mucosa. ${ }^{4}$ Several studies suggest a higher prevalence and severity of some pathologies in the oral tissues of patients with diabetes mellitus like gingivitis, periodontitis, dental caries, candidiasis, and other oral manifestations such as alteration of salivary flow and oral burning sensation. ${ }^{4}$

Several studies have examined the deleterious effects of diabetes on the oral mucosa. It was reported by Caldeira EJ et al that diabetes adversely affects the histomorphology of cheek mucosa, which may compromise tissue function to favour the occurrence of oral infections and probably neoplasia. $^{5}$

Although many of the pathological processes affecting the oral mucosa are clinically distinguishable, most lesions require a definitive diagnosis before commencement of appropriate therapy. The most accepted clinical technique for the diagnosis of lesions in the oral mucosa is incisional or excisional biopsy. ${ }^{6}$ However, in specific clinical conditions, such as diabetes mellitus, a great many invasive techniques are relatively contraindicated and necessitate the use of oral exfoliative cytology which may be suitable. ${ }^{4}$

As exfoliative cytology is considered a moderate and non-invasive technique when compared to conventional anatomopathological examination, it is necessary to make an assessment of the application of oral exfoliative cytological methods in patients with DM patients. ${ }^{4}$ This will help to better interpret the findings from specimens obtained from the mucosa of such affected persons. The best knowledge of this technique, particularly regarding the morphological and morphometric aspects of the cells may yet enable the implementation of exfoliative cytology in public health programs, comprising one more tool in the screening, diagnosis and follow-up of diabetes mellitus. ${ }^{4}$
The present study thus attempts to quantitatively and qualitatively assess changes in oral epithelial cells by exfoliative cytology to determine the effects of DM on the oral cavity.

\section{MATERIALS AND METHODS}

The present study was conducted in the Department of Oral Pathology and Microbiology, Manipal College of Dental Sciences, Mangalore and Kist Medical College, Imadol, Lalitpur over a period of 24 months from January 2010 to January 2012. The study involved a cytomorphometric analysis of the oral mucosa in patients with type 2 diabetes mellitus using smears obtained from buccal mucosa and dorsum of tongue.

Study Sample: The study comprised of a total of 60 subjects divided into two groups:

Study group: Consisting of thirty individuals above 40 years of age with a known history of type II diabetes mellitus for a minimum period of one year. The subjects with diabetes were selected from among the patients attending the dedicated Diabetic clinic of K. M. C. Hospital, Attavar Mangalore. Patients were included irrespective of whether they were under insulin or oral hypoglycaemic therapy for diabetes.

Control group: Consisted of thirty age and sex-matched healthy individuals without any history of diabetes mellitus ${\text { (assessed by random blood sugar }{ }^{6}}^{6}$

\section{Exclusion criteria}

Patients/ individuals with the following were excluded from the study:

Table 8: Review of Cytomorphometric studies in DM

\begin{tabular}{|c|c|c|c|c|c|c|c|c|}
\hline \multirow{2}{*}{ SN } & \multirow{2}{*}{ Author } & \multirow{2}{*}{$\mathrm{N}$} & \multicolumn{4}{|c|}{ Diabetic Group compared to control } & \multicolumn{2}{|c|}{ Comparison with our study } \\
\hline & & & $\mathrm{NuA}$ & $\mathrm{CA}$ & CyA & $\mathrm{N} / \mathrm{C}$ ratio & Similar & Dissimilar \\
\hline \multirow{2}{*}{1} & \multirow{2}{*}{ Alberti et al4 } & Cases 10 & \multirow{2}{*}{$\begin{array}{l}\text { Increased } \\
\mathrm{P}=<0.05\end{array}$} & \multirow{2}{*}{ NM } & \multirow{2}{*}{$\begin{array}{l}\text { Decreased } \\
\mathrm{P}=\mathrm{NS}\end{array}$} & \multirow{2}{*}{$\begin{array}{l}\text { Increased } \\
\mathrm{P}=<0.05\end{array}$} & \multirow{2}{*}{$\begin{array}{l}\mathrm{NuA} \\
\mathrm{N} / \mathrm{C} \text { ratio }\end{array}$} & \multirow{2}{*}{ CyA } \\
\hline & & Controls 10 & & & & & & \\
\hline \multirow[b]{2}{*}{2} & \multirow[b]{2}{*}{ Jajarm et al13 } & Cases 30 & \multirow[b]{2}{*}{$\begin{array}{l}\text { Increased } \\
\mathrm{P}=<0.0001\end{array}$} & \multirow[b]{2}{*}{ NM } & \multirow[b]{2}{*}{$\begin{array}{l}\text { Increased } \\
\mathrm{P}=<0.0001\end{array}$} & \multirow[b]{2}{*}{$\begin{array}{l}\text { Increased } \\
\mathrm{P}=<0.0001\end{array}$} & \multirow{2}{*}{$\begin{array}{l}\text { NuA } \\
\text { CyA } \\
\text { N/C ratio }\end{array}$} & \\
\hline & & Controls 30 & & & & & & \\
\hline \multirow{2}{*}{3} & \multirow{2}{*}{ Shareef et al14 } & Cases 10 & \multirow{2}{*}{$\begin{array}{l}\text { Increased } \\
\mathrm{P}=0.014\end{array}$} & \multirow{2}{*}{ NM } & \multirow{2}{*}{$\begin{array}{l}\text { Decreased } \\
\mathrm{P}=0.705\end{array}$} & \multirow{2}{*}{$\begin{array}{l}\text { Increased } \\
\mathrm{P}=0.002\end{array}$} & \multirow{2}{*}{$\begin{array}{l}\mathrm{NuA} \\
\mathrm{N} / \mathrm{C} \text { ratio }\end{array}$} & \multirow{2}{*}{ CyA } \\
\hline & & Controls 10 & & & & & & \\
\hline \multirow{2}{*}{4} & \multirow{2}{*}{$\begin{array}{l}\text { Tozoglu U et al15 } \\
\text { Volume }\end{array}$} & Cases 40 & \multirow{2}{*}{$\begin{array}{l}\text { Increased } \\
\mathrm{P}=0.0000 \\
\text { Nuclear volume }\end{array}$} & \multirow{2}{*}{$\begin{array}{l}\text { Decreased } \\
\mathrm{P}=0.0000 \\
\text { Cell volume }\end{array}$} & \multirow[b]{2}{*}{ NM } & \multirow[b]{2}{*}{ NM } & \multirow[b]{2}{*}{$\mathrm{NuA}$} & \multirow[b]{2}{*}{ CA } \\
\hline & & Cases 30 & & & & & & \\
\hline \multirow[b]{2}{*}{5} & \multirow{2}{*}{$\begin{array}{l}\text { Prasad H et al16 } \\
\text { Diameter }\end{array}$} & Cases 50 & Increased & $\begin{array}{l}\text { Marginal Decrease } \\
\mathrm{P}=0.1527\end{array}$ & $\begin{array}{l}\text { Decreased } \\
\mathrm{P}=0.0934\end{array}$ & Increased & $\mathrm{NuA}$ & $\mathrm{CA}$ \\
\hline & & Controls 5 & $\begin{array}{l}P=0.0367 \\
\text { ND }\end{array}$ & $\mathrm{CD}$ & CyD & $\mathrm{P}=0.1164$ & $\mathrm{~N} / \mathrm{C}$ ratio & СуА \\
\hline & & Cases 30 & Increased & Increased & Increased & Increased & & \\
\hline 0 & ail study $(2011)$ & Controls 30 & & & & & & \\
\hline
\end{tabular}


Table 1: Descriptive data for various parameters

\begin{tabular}{|c|c|c|c|c|c|c|c|}
\hline SN & Parameter & Category & $\mathbf{N}$ & Minimum & Maximum & Median & Interquartile range \\
\hline \multirow{2}{*}{1} & \multirow{2}{*}{ NuA BM } & Cases & 30 & 37.20 & 81.92 & 51.80 & $19.46(48.11,67.57)$ \\
\hline & & Control & 30 & 34.30 & 95.84 & 46.28 & $10.57(39.60,50.18)$ \\
\hline \multirow{2}{*}{2} & \multirow{2}{*}{$\begin{array}{l}\text { NuA } \\
\text { Tongue }\end{array}$} & Cases & 30 & 36.55 & 75.66 & 54.02 & $16.55(48.09,64.64)$ \\
\hline & & Controls & 30 & 32.42 & 85.82 & 41.93 & $8.27 \quad(39.53,47.80)$ \\
\hline \multirow{2}{*}{3} & \multirow{2}{*}{$\begin{array}{l}\mathrm{NuA} \\
\text { Total }\end{array}$} & Cases & 30 & 36.88 & 73.79 & 53.96 & $18.98(47.98,66.95)$ \\
\hline & & Controls & 30 & 33.94 & 73.63 & 44.13 & $9.57 \quad(40.37,49.95)$ \\
\hline \multirow{2}{*}{4} & \multirow{2}{*}{ CA BM } & Cases & 30 & 1170.87 & 2742.79 & 1963.79 & $689.85(1573.91,2263.75)$ \\
\hline & & Controls & 50 & 1306.61 & 2666.12 & 1623.13 & $289.27(1501.74,1791.01)$ \\
\hline \multirow{2}{*}{5} & \multirow{2}{*}{$\begin{array}{c}\text { CA } \\
\text { Tongue }\end{array}$} & Cases & 30 & 1093.47 & 2689.18 & 1990.41 & $606.06(1701.02,2307.09)$ \\
\hline & & Controls & 50 & 1264.78 & 2438.58 & 1599.60 & $643.10(1429.44,2072.54)$ \\
\hline \multirow{2}{*}{6} & \multirow{2}{*}{$\begin{array}{l}\mathrm{CA} \\
\text { Total }\end{array}$} & Cases & 30 & 1355.71 & 2682.00 & 1965.90 & $542.97(1676.60,2219.56)$ \\
\hline & & Controls & 30 & 1308.99 & 2396.76 & 1662.52 & $338.53(1540.01,1878.53)$ \\
\hline \multirow{2}{*}{7} & \multirow{2}{*}{ СуA BM } & Cases & 30 & 1122.59 & 2660.87 & 1925.76 & $685.68(1519.31,2204.99)$ \\
\hline & & Controls & 30 & 1254.37 & 2615.45 & 1578.18 & $277.90(1459.00,1736.89)$ \\
\hline \multirow{2}{*}{8} & \multirow{2}{*}{$\begin{array}{l}\text { CyA } \\
\text { Tongue }\end{array}$} & Cases & 30 & 1265.96 & 2616.74 & 1993.55 & $588.10(1660.90,2248.99)$ \\
\hline & & Controls & 30 & 1210.20 & 2435.64 & 1554.28 & $655.08(1371.38,2032.46)$ \\
\hline \multirow{2}{*}{9} & \multirow{2}{*}{ CyA Total } & Cases & 30 & 1300.58 & 2608.21 & 1922.52 & $517.94(1633.25,2248.99)$ \\
\hline & & Controls & 30 & 1255.91 & 2346.00 & 1616.07 & $344.22(1489.34,2032.46)$ \\
\hline \multirow{2}{*}{10} & \multirow{2}{*}{$\begin{array}{c}\text { N/C Ratio } \\
\text { BM }\end{array}$} & Cases & 30 & 0.021 & 0.063 & 0.034 & $0.020(0.026,0.046)$ \\
\hline & & Controls & 30 & 0.015 & 0.014 & 0.031 & $0.009 \quad(0.026,0.035)$ \\
\hline \multirow{2}{*}{11} & \multirow{2}{*}{$\begin{array}{l}\text { N/C Ratio } \\
\text { Tongue }\end{array}$} & Cases & 30 & 0.018 & 0.078 & 0.032 & $0.012(0.0296,0.042)$ \\
\hline & & Controls & 30 & 0.017 & 0.070 & 0.028 & $0.016(0.022,0.039)$ \\
\hline \multirow{2}{*}{12} & \multirow{2}{*}{$\begin{array}{c}\text { N/C Ratio } \\
\text { Total }\end{array}$} & Cases & 30 & 0.0035 & 0.0614 & 0.0332 & $0.0142(0.029,0.042)$ \\
\hline & & Controls & 30 & 0.0166 & 0.0904 & 0.0293 & $0.0107(0.0266,0.039)$ \\
\hline
\end{tabular}

CA-Cellular area, CyA-Cytoplasmic area, N/C-Nucleus: cytoplasm, BM-Buccal mucosa,

\begin{tabular}{|c|c|c|c|c|}
\hline Parameters & Category & $\mathbf{N}$ & Mean & $\begin{array}{l}\text { Standard Deviation } \\
\text { (SD) }\end{array}$ \\
\hline \multirow{2}{*}{ FBS } & Cases & 15 & 162.2 & 41.96 \\
\hline & Controls & - & & \\
\hline \multirow{2}{*}{ FBS } & Cases & 11 & 241.19 & 63.99 \\
\hline & Controls & 15 & 99.06 & 13.54 \\
\hline \multirow{2}{*}{ PP sugar level } & Cases & 4 & 221.75 & 36.22 \\
\hline & Controls & - & & \\
\hline \multirow{2}{*}{ Hemoglobin } & Cases & 30 & 13.08 & 1.56 \\
\hline & Controls & 30 & 13.09 & 1.74 \\
\hline
\end{tabular}

1. Habits of smoking or betel nut chewing.

2. Medication for systemic disease other than diabetes mellitus.

3. Known cases of malignancy.

4. Patients who have undergone radiation therapy and chemotherapy
5. Subjects with poor oral hygiene.

6. Denture wearers

7. Clinical evidence of premalignancy

8. Alcohol dependency (based on CAGE questionnaire) ${ }^{7}$

\section{Inclusion criteria}

1. Patients between above 40 yrs with clinically healthy oral mucosa

2. Medical history of type II Diabetes mellitus for a minimum period of 1 year and patients irrespective of whether they were under any medication for diabetes or not.

3. Diagnostic criteria for type II diabetes mellitus were as follows: ${ }^{8}$

a. Random serum glucose concentration $>200 \mathrm{mg} / \mathrm{dl}$ (11.1mM); or

b. Fasting serum glucose level $>126 \mathrm{mg} / \mathrm{dl}(7.0 \mathrm{mM})$; or 
Table 3: Assessment of variations between cases and controls using Mann Whitney $U$ test

\begin{tabular}{|c|c|c|c|c|c|c|}
\hline SN & Parameter & Category & $\mathbf{N}$ & Mean rank & $\mathbf{Z}$ & p value \\
\hline \multirow{2}{*}{1} & \multirow{2}{*}{ NuA BM } & Cases & 30 & 38.27 & \multirow{2}{*}{-3.445} & \multirow{2}{*}{0.000057} \\
\hline & & Control & 30 & 22.73 & & \\
\hline \multirow{2}{*}{2} & \multirow{2}{*}{$\begin{array}{l}\text { NuA } \\
\text { Tongue }\end{array}$} & Cases & 30 & 40.40 & \multirow{2}{*}{-4.391} & \multirow{2}{*}{0.0000113} \\
\hline & & Controls & 30 & 20.60 & & \\
\hline \multirow{2}{*}{3} & $\mathrm{NuA}$ & Cases & 30 & 39.40 & \multirow{2}{*}{-3.947} & \multirow{2}{*}{0.000079} \\
\hline & Total & Controls & 30 & 21.60 & & \\
\hline \multirow{2}{*}{4} & \multirow{2}{*}{ CA BM } & Cases & 30 & 34.97 & \multirow{2}{*}{-1.981} & \multirow{2}{*}{0.0475} \\
\hline & & Controls & 30 & 26.03 & & \\
\hline \multirow{2}{*}{5} & \multirow{2}{*}{$\begin{array}{c}\text { CA } \\
\text { Tongue }\end{array}$} & Cases & 30 & 36.27 & \multirow{2}{*}{-2.558} & \multirow{2}{*}{0.0105} \\
\hline & & Controls & 30 & 24.73 & & \\
\hline \multirow{2}{*}{6} & \multirow{2}{*}{$\begin{array}{l}\text { CA } \\
\text { Total }\end{array}$} & Cases & 30 & 36.83 & \multirow{2}{*}{-2.809} & \multirow{2}{*}{0.00496} \\
\hline & & Controls & 30 & 24.17 & & \\
\hline \multirow{2}{*}{7} & \multirow{2}{*}{ СуA ВM } & Cases & 30 & 34.77 & \multirow{2}{*}{-1.892} & \multirow{2}{*}{0.0584} \\
\hline & & Controls & 30 & 26.23 & & \\
\hline \multirow{2}{*}{8} & \multirow{2}{*}{$\begin{array}{l}\text { CyA } \\
\text { Tongue }\end{array}$} & Cases & 30 & 37.07 & \multirow{2}{*}{-2.913} & \multirow{2}{*}{0.00358} \\
\hline & & Controls & 30 & 23.93 & & \\
\hline \multirow{2}{*}{9} & \multirow{2}{*}{ CyA Total } & Cases & 30 & 37.27 & 3001 & 000268 \\
\hline & & Controls & 30 & 23.73 & -3.001 & 0.00268 \\
\hline & N/C Ratio & Cases & 30 & 33.33 & & \\
\hline 10 & BM & Controls & 30 & 27.67 & -1.257 & 0.208 \\
\hline 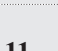 & N/C Ratio & Cases & 30 & 33.73 & & \\
\hline 11 & Tongue & Controls & 30 & 27.27 & -1.434 & 0.1515 \\
\hline & N/C Ratio & Cases & 30 & 34.17 & & \\
\hline 12 & Total & Controls & 30 & 26.83 & -1.626 & 0.1038 \\
\hline
\end{tabular}

Table 4: Pearson's correlation between the GLUCOSE levels and various morphometric parameters

\begin{tabular}{cccccl}
\hline SN & Parameter & R & R2 & F & p value \\
1 & Total Nuclear Area & 0.217 & 0.047 & 2.119 & 0.153 \\
2 & Total Cellular Area & 0.336 & 0.113 & 5.477 & 0.024 \\
3 & Total Cytoplasmic Area & 0.345 & 0.119 & 5.814 & 0.020 \\
4 & Total N/C Ratio & 0.083 & 0.007 & 0.300 & 0.587 \\
\hline
\end{tabular}

c. 2 hour plasma glucose $>200 \mathrm{mg} / \mathrm{dl}(11.1 \mathrm{mM})$

4. Control group of volunteers having clinically healthy oral mucosa and no clinical signs of systemic diseases and positive laboratory findings (absence of diabetes)

\section{Methods of collection of Data:}

Ethical clearance was obtained from the Institutional Ethics Committee (MCODS, Mangalore) and approval was taken from Department of Internal Medicine, KIST medical college. Subjects of both the study and control groups were informed of the procedure and a written consent was obtained. All the subjects were clinically examined to assess the oral hygiene and to exclude the possibility of any other oral disease or systemic disease with oral manifestations.

Table 5: Pearson's correlation between the HEMOGLO-
BIN levels and various morphometric parameters
\begin{tabular}{ccccccl}
\hline SN & Parameter & R & R2 & F & p value \\
1 & Total Nuclear Area & 0.149 & 0.022 & 0.955 & 0.334 \\
2 & Total Cellular Area & 0.192 & 0.37 & 1.610 & 0.211 \\
3 & Total Cytoplasmic Area & 0.149 & 0.22 & 0.959 & 0.333 \\
4 & Total N/C Ratio & 0.251 & 0.063 & 2.824 & 0.100 \\
\end{tabular}

For study groups, haematological assessment for blood glucose/glycosylated haemoglobin levels was obtained from patients' medical records.

\section{Cytomorphometric Assessment:}

Sample collection procedure: After detailed clinical examination, the subjects were requested to rinse the mouth with normal saline. Smears were obtained from the buccal mucosa $(\mathrm{BM})$ and the dorsum of tongue of each subject using a wooden spatula moistened in distilled water. Two smears from each site were obtained. The smears were transferred onto grease-free glass slides and fixed with $95 \%$ ethyl alcohol.

Two smears each from both the sites (buccal mucosa and 
Table 6: Forward stepwise Linear Regression coefficient for total cellular area (Deemed significant by Pearson's correlation) in relation to glucose level

\begin{tabular}{|c|c|c|c|c|}
\hline \multirow{2}{*}{ Modal } & \multicolumn{2}{|c|}{ Unstandardized Coefficients } & \multirow{2}{*}{$\mathbf{F}$} & \multirow{2}{*}{$\begin{array}{l}\text { Signifi- } \\
\text { cance }\end{array}$} \\
\hline & B & Std. Error & & \\
\hline \multirow{2}{*}{$\begin{array}{l}\text { (Constant) } \\
\text { Total cellular } \\
\text { area }\end{array}$} & 33.910 & 57.200 & \multirow[t]{2}{*}{5.477} & \multirow[t]{2}{*}{0.024} \\
\hline & 0.070 & 0.030 & & \\
\hline Gluce & level $=3$ & 0.070 (total c & ular a & \\
\hline
\end{tabular}

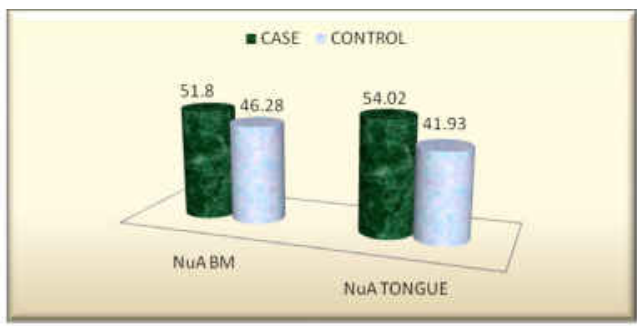

Graph 1: Indicating the distribution of Nuclear area (NuA) among cases and controls

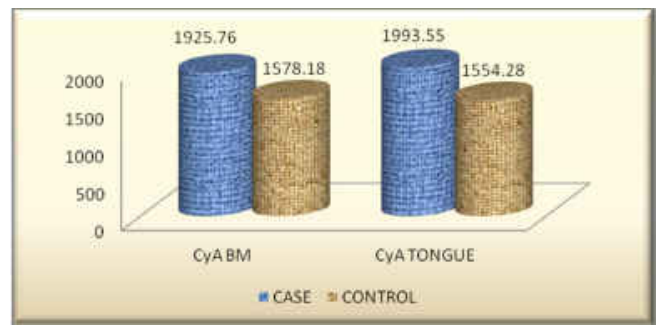

Graph 3: Indicating the distribution of Cytoplasmic area (CyA) among cases and controls

tongue) were stained with Papanicolaou stain to visualize under compound light microscope for cytomorphometric analysis of cells (for $\mathrm{NuA}, \mathrm{CA}, \mathrm{CyA}$ and $\mathrm{N} / \mathrm{C}$ ratio) using Image J software.

The other two smears from each site were stained with Acridine orange to visualize under fluorescence microscope for assessment of nuclear alterations like micronuclei, nuclear budding, binucleation, multinucleation and karyorrhexis. Cytomorphometric assessment was done in 50 cells of each PAP-stained smear. Nuclear alterations were also evaluated in 50 cells of each smear stained with Acridine orange and evaluated using the criteria set by Countryman and Heddle et al. ${ }^{9}$

\section{Statistical Analysis:}

The data was analysed using SPSS (Statistical Package for Social Sciences version 19) software. Mann Whitney U test was carried out to calculate the variations in the various
Table 7: Forward stepwise Linear Regression coefficient for total cytoplasmic area (Deemed significant by Pearson's correlation) in relation to glucose level

\begin{tabular}{ccccc}
\hline Modal & \multicolumn{2}{c}{ Unstandardized Coefficients } & F & $\begin{array}{c}\text { Signifi- } \\
\text { cance }\end{array}$ \\
\hline $\begin{array}{c}\text { (Constant) } \\
\text { Total cyto- } \\
\text { plasmic area }\end{array}$ & 28.359 & Std. Error & & \\
\multicolumn{4}{c}{ Glucose level $=28.359+0.075$ (total cytoplasmic area) }
\end{tabular}

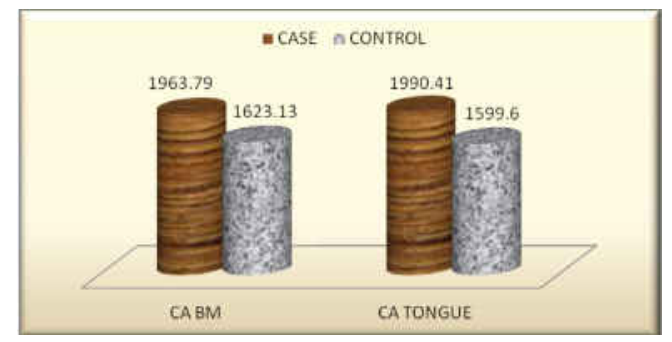

Graph 2: Indicating the distribution of Cellular area among cases and controls

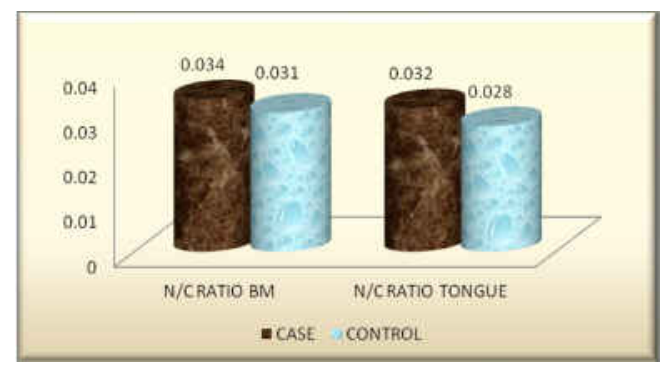

Graph 4: Indicating the distribution of Nucleus: cytoplasm ratio (N/C) among cases and controls

parameters (NuA, CA, CyA, N/C ratio) between cases and controls. Forward stepwise linear regression and Pearson's correlation was done to correlate various significant parameters in relation to glucose level.

\section{RESULTS}

Table 1 enumerates the various parameters showed that the total nuclear area was higher in cases $(53.96 \%)$ than in controls $(44.13 \%)$ in both recorded sites, i.e., tongue and buccal mucosa. The same trend of higher values was also seen in the total cellular area in cases (1965.90) compared to controls (1662.52). Likewise, total cytoplasmic area in cases (1922.52) was greater than in controls (1616.07) and total N/C ratio in cases $(0.0332)$ was also higher than in controls (0.0293) both in tongue as well as buccal mucosa.

Table 2 showed that the mean fasting blood sugar (FBS), random blood sugar (RBS) and postprandial blood sugar (PPS) of cases was 162.2 $\pm 41.96,241 \pm 63.99,221.75 \pm$ 
36.22 and $13.08 \pm 1.56$ while the mean RBS of controls was $99.06 \pm 13.54$. Similarly, the mean hemoglobin of cases was $13.08 \pm 1.56$ and that of controls was $13.09 \pm 1.74$.

As the data was found to follow a skewed distribution pattern, nonparametric tests were used to study the differences. Thus, Mann Whitney U test (Table 3) was applied to assess the variations between cases and controls for each of the variables. The increase in the Nuclear area (median for BM 51.80, Tongue 54.02) of cases was statistically significant among BM $(Z=-3.445, p=0.00006)$, Tongue $(Z=-4.391, p=0.0000113)$ and in total $(Z=-3.947$, $\mathrm{p}=0.00008$ ). Also, the increase in the Cellular area (median BM 1963.79, Tongue 1990.41) of cases was statistically significant among $\mathrm{BM}(\mathrm{Z}=-1.981, \mathrm{p}=0.0475)$, Tongue $(\mathrm{Z}=$ $-2.56, p=0.0105)$ and in total $(Z=-2.809, p=0.00496)$. The increase in the Cytoplasmic area (median Tongue 1993.55) in cases was statistically significant among Tongue $(Z=$ -2.913, $\mathrm{p}=0.00358)$ and total $(Z=-3.001, \mathrm{p}=0.00268)$ but was statistically insignificant in $\mathrm{BM}(\mathrm{Z}=-1.892, \mathrm{p}=0.06)$. However, the increase in $\mathrm{N} / \mathrm{C}$ ratio (median $\mathrm{BM} 0.034$, Tongue 0.032) among cases was statistically insignificant among $\mathrm{BM}(\mathrm{Z}=-1.257, \mathrm{p}=0.208)$, Tongue $(\mathrm{Z}=-1.434$, $\mathrm{p}=0.1515)$ and in total $(\mathrm{Z}=-1.626, \mathrm{p}=0.1038)$.

Correlation of glucose level with various parameters using linear regression (Table 4) showed slight to mild correlation. The total nuclear area showed slight correlation $(\mathrm{R}=0.217)$, the total cellular area $(\mathrm{R}=0.336)$ and total cytoplasmic area $(\mathrm{R}=0.345)$ showed mild correlation while the total $\mathrm{N} / \mathrm{C}$ ratio $(\mathrm{R}=0.083)$ showed no correlation with glucose levels.

Although, the glucose level values when compared with various parameters (Table 4) showed statistically significant correlation, only $11.3 \%$ of the total cellular area $(\mathrm{p}=0.024)$ and $11.9 \%$ of the total cytoplasmic area $(p=0.020)$ showed variation with alteration in glucose levels. By looking at $\mathrm{R}$ value and R2 value, the Cellular area explains only $11.3 \%$ of variation in glucose level $(\mathrm{R}=0.336, \mathrm{p}=0.024)$. Also by looking at $\mathrm{R}$ value and $\mathrm{R} 2$ value, the Cytoplasmic area explains only $11.9 \%$ of variation in glucose level $(\mathrm{R}=0.345$, $\mathrm{p}=0.02)$.

Forward stepwise linear regression was carried out for total CA and total CyA to confirm the cytomorphometric parameter (deemed significant by Pearson's correlation) correlating with glucose level changes. The regression equation derived for CA from the coefficient was Glucose level $=33.910+0.070$ (total cellular area). The regression equation indicated that for every one unit increase in cellular area, the glucose level increased by 0.07 units. (Table 6) The regression equation derived for $\mathrm{CyA}$ from the coefficient was Glucose level $=28.359+0.075$ (total cytoplasmic area). The regression equation indicated that for every one unit increase in cytoplasmic area, the glucose level increased by 0.075 units.(Table 7)

Comparison of hemoglobin level with various parameters using Pearson's correlation showed only slight to mild correlation. The total nuclear area $(\mathrm{R}=0.149)$, total cellular area $(\mathrm{R}=0.192)$ and total cytoplasmic area $(\mathrm{R}=0.149)$ showed slight correlation while the total $\mathrm{N} / \mathrm{C}$ ratio $(\mathrm{R}=0.251)$ showed mild correlation. The test further showed that only $37 \%$ of the total cellular area, $22 \%$ of the total cytoplasmic area, $2.2 \%$ of the total nuclear area, $6.3 \%$ of the total N/C ratio showed variation correlating with hemoglobin level and these were not statistically significant. (Table 5) Also the epithelial cells from the diabetic group showed features such as nuclear budding, micronuclei, binucleation, karyorrhexis and perinuclear halo as seen in figure (1-6).

\section{DISCUSSION}

\section{Diabetes Mellitus and Cytomorphometry:}

Diabetes Mellitus (DM) is a syndrome characterized by abnormal carbohydrate, fat and protein metabolism that results in acute or chronic complications due to absolute or relative lack of insulin. ${ }^{9}$ Type 2 diabetes mellitus is the fifth most common chronic condition and the sixth leading cause of mortality among the elderly worldwide. ${ }^{10}$

Dentists come across various oral manifestations of this disease. Proper understanding of DM enables early diagnosis that is helpful in control of blood sugar level at an early stage to prevent various complications. Several studies have examined the deleterious effects of DM on oral mucosa with reports stating its adverse effects on the morphology of oral mucosa, which in turn may compromise tissue function to favour the occurrence of oral infections and oral neoplasia. In diabetes, there is a loss of oxidation equilibrium whereby the activities of the antioxidant scavengers and enzymes are depressed by elevated glucose concentration, excessive formation of free radicals and protein glycation. These noxious processes can cause serious damage to the biological structures at a molecular level which can be appreciated by oral exfoliative cytology which has been improved immensely by incorporation of techniques like computer-aided morphometry, making it more reliable, objective and reproducible..$^{5,11,12}$

The present study evaluated the morphometric and cytologic changes in the exfoliated cells of apparently normal buccal and tongue mucosa in type 2 diabetic patients. There was a significant increase in Nuclear area $(\mathrm{NuA})$ obtained from both the sites i.e., buccal mucosa and tongue in the study group. (Graph 1)This finding concurs with the studies done by Alberti et $\mathrm{al}^{4}$, Jajarm et $\mathrm{al}^{13}$, Shareef et $\mathrm{al}^{14}$, Tozoglu U and Bilge $\mathrm{OM}^{15}$ and Prasad $\mathrm{H}$ et $\mathrm{al}^{16}$ where the mean $\mathrm{NuA}$ was significantly higher among the diabetic group.(Table 8)

The increase in $\mathrm{NuA}$ among the study group could be explained by delay in keratinisation of oral epithelium, effects of ageing, dehydration/atrophy and inflammatory

Delay in the keratinisation is attributed to glycation changes. 


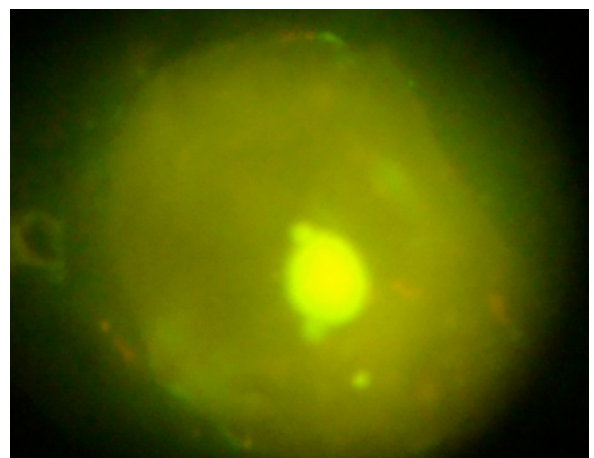

Figure 1: Photomicrograph showing nuclear budding around the nucleus in fuorescent microscopy (Acridine Orange,X100).

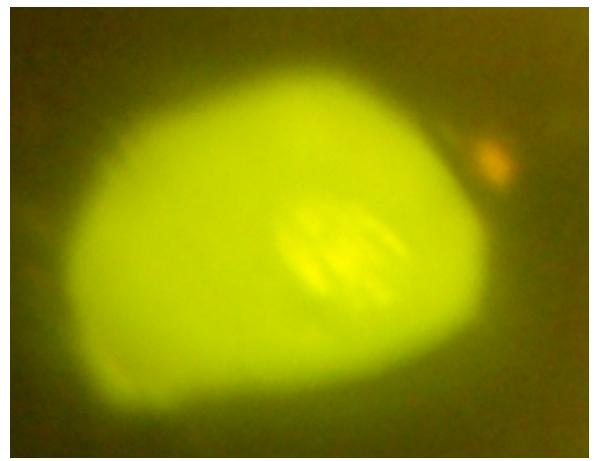

Figure 3: Photomicrograph showing Karyorrhexis in fluorescent microscopy (Acridine Orange,X100).

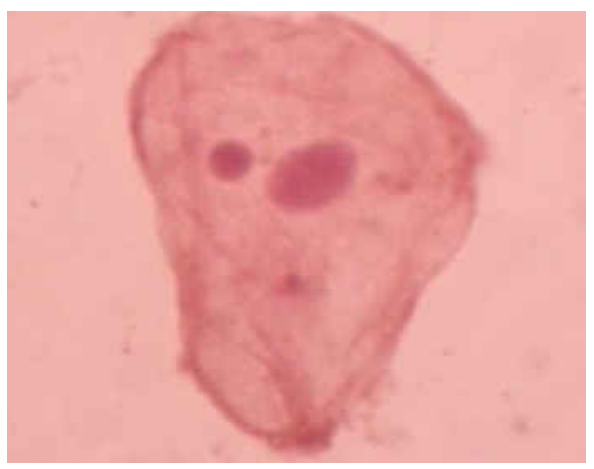

Figure 5: Photomicrograph showing a micronucleus in conventional bright field microscopy (Pap, X100).

Sustained hyperglycaemia causes greater accumulation of advanced glycation end products by abnormal glycation of proteins, lipids and nucleic acids in the walls of large blood vessels as well as in the basement membrane of the microvasculature. The progressive narrowing of the vessel lumen leads to decreased perfusion of the affected tissue and consequently decreases cell turnover thereby explaining the delay in the keratinisation process of the epithelium. This delay in the process of epithelial differentiation leads to an increase in the number of mature cells which show a large

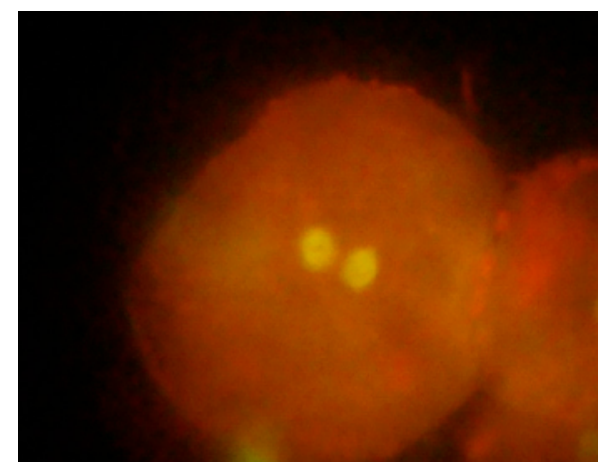

Figure 2: Photomicrograph showing a binucleated cell in fluorescent microscopy (Acridine Orange,X100).

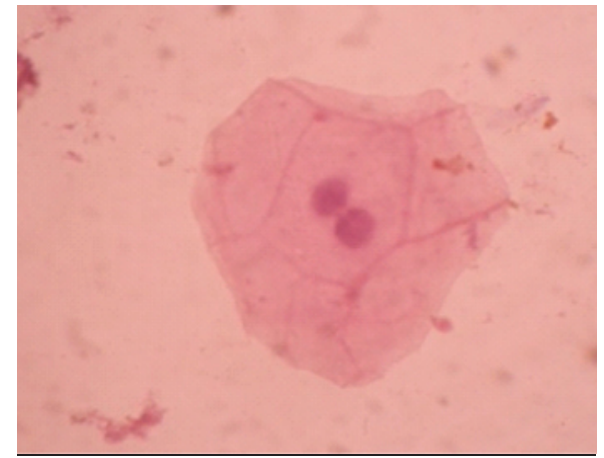

Figure 4: Photomicrograph showing a binucleated oral mucosal cell in conventional bright field microscopy (Pap,X100).

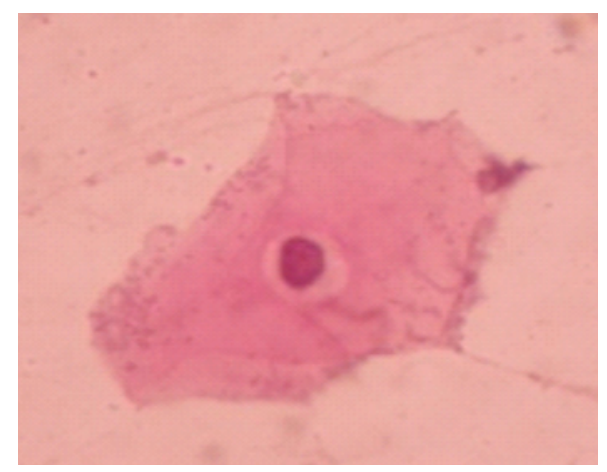

Figure 6: Photomicrograph showing a perinuclear halo in conventional bright field microscopy (Pap,X100).

nucleus as a primary characteristic., ${ }^{43}$

Type 2 DM is a disease of the elderly and generally occurs in patients over 40 years of age. Cellular ageing produces various morphologic alterations and genotoxic damages in cells in the form of pleomorphism, bilobed nuclei, micronucleus, nuclear budding, karyorrhexis, perinuclear halo which were also observed in the smears from diabetic patients in the present study. ${ }^{16}$ (figure 1-7) 


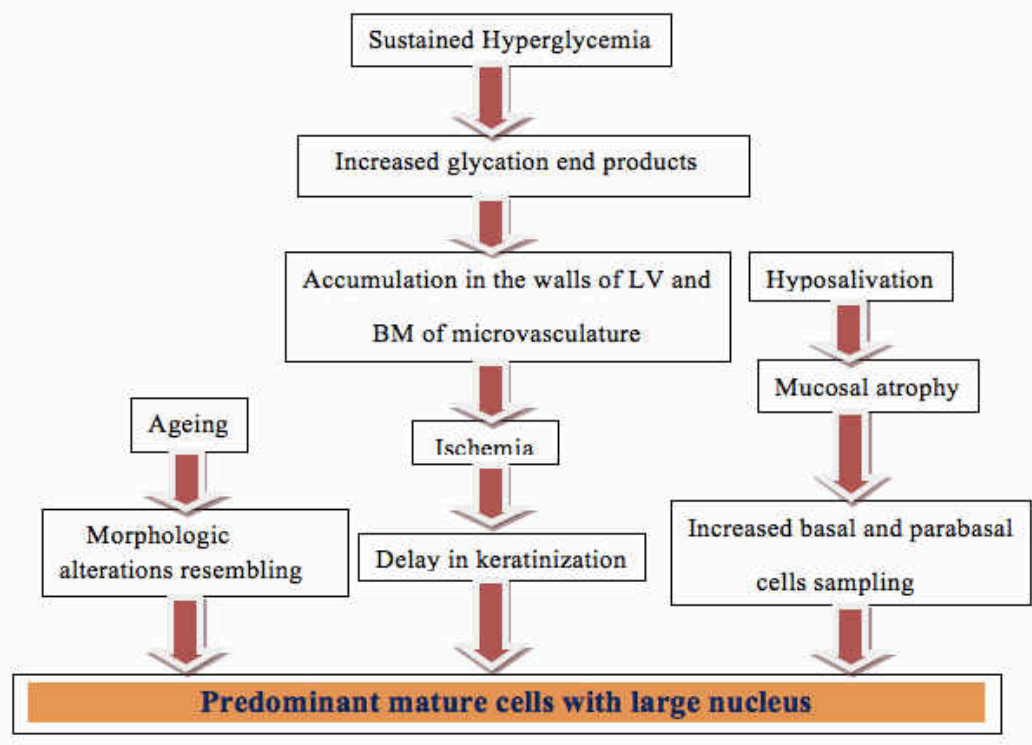

Figure 7: : Flow chart depicting mechanism for nuclear size alteration in DM; LV-Large vessel; BM-Basement membrane

Diabetic patients also suffer from dehydration due to the decreased salivary flow rates that may lead to mucosal atrophy. So, when smears from atrophic oral mucosa are made, the larger basal/spinous cells are inadvertently included in the sample. Thus, the primary pattern encompasses non-keratinized cells of parabasal layers which are smaller in cell size but have relatively larger nuclei; thus giving an impression of nuclear enlargement, with or without pleomorphism. ${ }^{4,16}$

Inflammation has been attributed to nuclear changes observed in various lesions. Reactive nuclear changes due to inflammation may erroneously mimic pleomorphism / atypia or may even suggest malignancy. ${ }^{17}$ Inflammation clinically manifests as superficial erosions or ulcerations of the oral mucosa seen as diffuse stomatitis and gingivitis. Cytomorphometric changes in the buccal mucosal cells of cigarette smokers similar to those noted in diabetics have been reported by Ogden et al. ${ }^{18}$

In the present study, there was a significant increase in Cellular area (CA) of epithelial cells obtained from both the sites, i.e., buccal mucosa and tongue among the study group.(Graph 2) Cytoplasmic area (CyA) from tongue also showed an increase in area which was statistically significant $(p=0.00268) .(G r a p h 3)$ This is similar to the findings of Prasad $\mathrm{H}$ et all6 who found an increase in cellular diameter (CD) among poorly controlled diabetics (PCD) and a similar study by Jajarm et a ${ }^{13}$ who also found a significant increase in CyA in the diabetic group. However, Shareef et $\mathrm{al}^{14}$ in a similar study found a statistically significant decrease in CyA which could be due to the cell shrinkage caused by dehydration. (Table 8 ) This theory is supported by the findings of Ogden et al ${ }^{19}$ who reported a similar decrease in CyA in patients with alcoholism.

This increase in CA and CyA could be because of the altered cell membrane integrity leading to excessive accumulation of lipid droplets in the cytoplasm thus creating an increased intercellular space as reported by Caldeira EJ et $\mathrm{al}^{5}$ in an experimental animal study where they examined the alterations in the histology and ultrastructure of oral epithelium of diabetic mice. In another experimental study in mice with diabetic retinopathy, Pannicke et al20 indicated that altered properties of $\mathrm{K}+$ channels, arachidonic acid metabolites and acute oxidative stress could be the cause for the development of cell swelling (cytotoxic edema) in the glial cells of retina under ischemic and inflammatory conditions. A similar pathogenesis could be projected for increase in CA and CyA of oral exfoliated mucosal cells observed in our study.

In the present study, an increase in Nucleus: cytoplasm (N/C) ratio was evident in patients with type $2 \mathrm{DM}$, (Graph 4) a finding similar to Alberti et al, ${ }^{4}$ Jajarm et al, ${ }^{13}$ Shareef et al, ${ }^{14}$ and Prasad $\mathrm{H}$ et a ${ }^{16}$ though it was not statistically significant. (Table 8) The relatively greater increase in nuclear size compared to cytoplasmic volume may explain this phenomenon.

Thus, cytomorphometry may be an efficient tool to understand the extent of cellular changes that occur in oral epithelial cells in diabetics that are secondary to microscopic changes like vascular occlusion and molecular changes such as oxidative stress. Therefore, cytomorphometric analysis of oral mucosal cells could be implicated as a non-invasive technique for screening and monitoring of the disease status in diabetic patients.

\section{CONCLUSION}

In recent years important advances in various invasive techniques have been made for screening and diagnosing diabetes mellitus along with new strategies for its effective 
treatment. However, in diabetes, use of an invasive technique is a relative contraindication due to changes in blood glucose concentrations and the disease itself. Exfoliative cytology used to evaluate cytomorphometric changes in the oral mucosa in diabetics along with oral candidal colonization may be a promising tool to gauge the molecular/serological alterations in diabetes mellitus.

Two Papanicolaou stained smears each from buccal mucosa and tongue were visualized under compound light microscope for measurement of Nuclear area (NuA), Cellular area (CA) using Image $\mathrm{J}$ software and further calculation of Cytoplasmic area (CyA) and Nucleus: Cytoplasm ratio (N/C ratio). The smears were also assessed using Acridine orange under fluorescence microscope for genotoxic nuclear alterations like micronuclei, nuclear budding, binucleation, multinucleation and karyorrhexis. The oral rinse was used for assessment of candidal colonization.

In the light of the present study, following conclusions have been derived from cytomorphometric analysis of exfoliated oral epithelial cells:

1. Significant increase in Nuclear Area among diabetics when compared to non-diabetics

2. Significant increase in Cellular Area and Cytoplasmic Area among diabetics when compared to non-diabetics

3. Non-significant increase in Nucleus: Cytoplasm ratio among diabetics when compared to non-diabetics

The increase in NuA among the study group could be explained by delay in keratinisation of oral epithelium, ageing effect, dehydration /atrophy and inflammatory process. The increase in CA and CyA could be attributed to the alteration of the properties of $\mathrm{K}+$ channels i.e. decrease conductance of $\mathrm{K}+$ ions in response to arachidonic acidinduced intracellular $\mathrm{Na}+$ overload and acute oxidative stress leading to cell swelling. The increase in $\mathrm{N} / \mathrm{C}$ ratio could be due to relatively greater increase in nuclear size compared to cytoplasmic volume. The objective demonstration of cytomorphometric and nuclear alterations by the oral exfoliated cells indicate the presence of cytological changes in the oral mucosa of diabetic patients despite the apparently normal clinical appearance. Hence, cytomorphometric analysis would aid the health professional as an additional non-invasive tool for the screening and monitoring of DM. While these alterations cannot be considered predictive or diagnostic for diabetes as they are not unique to this disease.

\section{REFERENCES}

1. Alberti KG, Zimmet PZ. Definition, diagnosis and classification of diabetes mellitus and its complication. Part 1: diagnosis and classification of diabetes mellitus provisional report of a WHO consultation. Diabet Med 1998;15:539-53. Crossref
2. Skamagas M, Breen TL, LeRoith D. Update on diabetes mellitus: prevention, treatment, and association with oral diseases. Oral Diseases 2008;14:105-14. Crossref

3. World Health Organisation. Definition, diagnosis and classification of diabetes mellitus and its complications. Geneva: WHO 1999. pp12 .

4. Alberti S, Spadella CT, Francischone TRCG, Assis GF, Cestari TM, Taveira LAA. Exfoliative cytology of the oral mucosa in type II diabetic patients: morphology and cytomorphometry. J Oral Pathol med 2003;32:538-43. Crossref

5. Caldeira EJ, Garcia PJ, Minatel E, Camilli JA, Cagnon VHA. Morphometric Analysis and Ultrastructure of the epithelium of the oral mucosa in diabetic autoimmune NOD mice. Braz J Morphol Sci 2004;21:197-205.

6. Jones AC, Pink FE, Sandow PL, Stewart CM, Baughman RA. The Cytobrush Plus cell collector in oral cytology. Oral Surg Oral Med Oral Pathol 1994;77:101-4. Crossref

7. Fauci AS, Braunwald E, Kasper DL, Hauser SL, Longo DL, Jameson JL, et al., editors. Harrison's principles of internal medicine. 17th ed. New York: McGraw Hill; 2008. pp2152-8.

8. Guggenheimer J, Moore PA, Rossie K et al. Insulin-dependent diabetes mellitus and oral soft tissue pathologies II. Prevalence and characteristics of Candida and candidal lesions. Oral Surg Oral Med Oral Pathol Oral Radiol Endod 2000;89:570-6. Crossref

9. Countryman PI, Heddle JA. The production of micronuclei from chromosome aberrations in irradiated cultures of human lymphocytes. Mutat Res 1976;41:321-32. Crossref

10. Chavez EM, Borrell LN, Taylor GW, Ship JA. A longitudinal analysis of salivary flow in control subjects and older adults with type 2 diabetes. Oral Surg Oral Med Oral Pathol Oral Radiol Endod 2001;91:116-73 Crossref

11. Ajit Auluck. Diabetes Mellitus: An Emerging Risk Factor for oral cancer? JCDA 2007; 73: 501-503. Crossref

12. Ujpal M, Matos O, Bibok G. Diabetes and oral tumors in Hungary: Epidemiological correlation. Diabetes Care 2004;27:770-4. Crossref

13. Jajarm HH, Mohtasham N, Rangiani A. Evaluation of oral mucosa epithelium in type II diabetic patients by an exfoliative cytology method. Journal of Oral Science 2008;50:335-40. Crossref

14. Shareef BT, Ang KT, Naik VR. Qualitative and quantitative exfoliative cytology of normal oral mucosa in type 2 diabetic patients. Med Oral Patol Oral Cir Bucal 2008;13:E693-6. Crossref

15. Tozoglu U, Bilge OM. Exfoliative Cytology of Type I Diabetic Patients. European Journal of General Medicine 2010;7:264-8. 
16. Prasad H, Ramesh V, Balamurali PD. Morphologic and cytomorphometric analysis of exfoliated buccal mucosal cells in diabetes patients. J Cytol 2010;27:113-7. Crossref

17. Koss LG, Melamed MR. Koss' Diagnostic Cytology and Its Histopathologic Bases. 5thed. Philadelphia: Lippincott Williams \& Wilkins. 2006. Pp pp 55-58.

18. Ogden GR, Cowpe JG, M W Green. Quantitative exfoliative cytology of normal buccal mucosa: effect of smoking. J Oral Pathol Med 1990;19:53-5. Crossref
19. Ogden GR, Wright AJ, Rice P. Effect of alcohol on the oral mucosa assessed by quantitative cytomorphometry. J Oral Pathol Med 1999;28:216-20. Crossref

20. Pannicke T, Iandiev I, Wurm A et al. Diabetes Alters Osmotic Swelling Characteristics and Membrane Conductance of Glial Cells in Rat Retina. Diabetes 2006;55:633-9. Crossref 